\title{
EFFECT OF FINANCIAL DEVELOPMENT ON FINANCIAL INNOVATION IN NIGERIA
}

\author{
Eunice Oluganna ${ }^{1}$ \\ Department of Accounting and Finance, Kwara State University \\ Malete, Kwara State, Nigeria. \\ E-mail: olugannaeunice@gmail.com \\ Tajudeen Lawal \\ Department of Accounting and Finance, Kwara state University \\ MaleteKwara State Nigeria. \\ E-mail: Ltajudeen@yahoo.com, tajudeen.lawal@kwasu.edu.ng
}

\begin{abstract}
Daniya Adeiza Abdulazeez
Department of Entrepreneurship and Business Studies, Federal University of Technology

Minna, Niger State- Nigeria

E-mail: daniyad3rd@yahoo.com
\end{abstract}

\begin{abstract}
Financial sector is crucial for the development of a well-functioning market as it facilitate capital inflows, mobilize savings for productive investment and facilitates the conduct and growth of an economy in the world. Despite the importance of financial sector development in Nigeria, financial institution operating in financial market were confronted with drastic changes where by old ways of doing business were no longer profitable and sustainable and unable to acquire fund with their traditional financial instruments. Against this background, the study investigated the effect of financial sector development on financial innovation in Nigeria. The study employed secondary data obtained from central bank of Nigeria statistical bulletin and World Bank database between 2011 and 2017. The data obtained was subjected to system General Method of Analysis (GMM) estimator. The study concluded that upward trend of process innovation significantly influence the in depth of finance. The study recommends policy makers should design policies which will promote and enhance the relationship between financial innovation and financial development in other to increase the supply and provision of financial service.

Keywords: Financial development, Financial innovation, Capital inflows, Investment, General Method of Analysis

\section{INTRODUCTION}

Financial sector development is one of the strong pillars and a determinant of a wellfunctioning market as it facilitate capital inflows, mobilize savings for productive

investment and facilitates the conduct and growth of an economy in the world. As a result of this importance, various sector of the economy depend on the financial sector for growth since no economy performs without
\end{abstract}

\footnotetext{
${ }^{1}$ Corresponding author, email: olugannaeunice@gmail.com
} 
finance. This system perform multiple functions such as liquidity provision, risk management, ensuring savings from surplus economic units are efficiently mobilized and shifted to high yielding investment in deficit economic unit with an appropriate balance of risk and returns among others. Supporting this view, Zacchaeus and Muturi (2017) noted that for financial development to have a desired impact there has to be a clear channel of linkages to innovation

Financial innovation has been seen as the improvement in the array of technological advances which facilitate access to information, trading and means of payment, emergence of new financial instrument and services, new forms of organization and more developed and complete financial markets (Gennaioli, Shleifer and Vishny, 2012). For financial innovation to be successful, it must either reduce risk and cost of activity to foster the accumulation of capital or provide and improved service that meets the particular needs of financial system participants. Thus, it influences the structure of financial market, financial behavior of economic agents, the types of financial product traded and adds uncertainty to the financial environment in which the $\mathrm{CBN}$ conduct monetary operations (Ho, 2006).
Earlier before 2000s, financial institution operating in financial market were confronted with drastic changes where by old ways of doing business were no longer profitable and sustainable; they were no longer able to acquire fund with their traditional financial instruments and without these funds they would be out of business. In the consolidation and merger that took place in the late 2007s, the ability of Nigerian banks to satisfy and retain their customers in the post-consolidation era in no doubt depend largely on the development of innovations Jegede (2014) because countries where more loanable fund are spent on financial innovation are better able to translate opportunities in the financial institution. In the bid to catch up with global developments and improve the quality of their service delivery, Nigerian banks widely adopted financial innovation for delivering a wide range of value-added products and services, such as automated teller machines (ATMs), automated clearing houses, point of sale systems, telephone transfers, automatic bill payer accounts, credit cards among others. This situation makes bank to operate efficiently and effectively. In fact according to Central Bank of Nigeria, (2017) the number of electronic payment transaction increased by 32.5 percent to N83.1 trillion, 
from 62.7 trillion in 2016. Despite this impressive landmark access to finance is still relatively low. Hence, this inadequate supply of money hinders the expansion of the financial innovation and in turn brings under development in the financial sector.

For robust empirical investigation, the study adopts the one of the innovation since the study cannot view all the financial innovation hence, the study restrict itself to process innovation because Nigeria is a developing country. There is none in existence in Nigeria to the best of the researchers' knowledge; hence this is the only study that looks at the effect of the former on the latter in Nigeria. The time frame for the study is 2011 to 2017 . This period is considered because the central bank of Nigeria kicks off the business of cashless transaction in 2011, which is the latest form of financial innovations in the financial institution. Hence, this study is restricted to the period 2011 to 2017, to examine how these innovation increases the provision of financial service to the populace. The findings of previous researchers cannot be generalize because of the peculiarity of each country, hence this study is worth undertaking. This study therefore intends to fill and add to these pertinent gaps in literature.
In line with the problem statement, the study seeks to examine the effect of financial innovation on financial sector development in the Nigeria.

\section{LITERATURE REVIEW AND HYPOTHESIS DEVELOPMENT}

\section{Financial Sector Development and} Financial Innovation

The rapid pace of technical change in the financial sector has led to the development of digital platform which allows not only the broader distribution of financial services provided by traditional financial institutions, but also the popularization of peer-to-peer lending and equity financing (crowdfunding) beyond the boundaries of traditional financial institutions (Batiz-Lazo and Woldesenbet, 2006). As argued by (Zacchaeus and Muturi, 2017) an efficient financial sector development is one of the strong pillars of a well-functioning market economy, as it form the structure of arrangements and facilitates the conduct and growth of economic transaction through the use of money for payments, savings and investment. (Nzotta and Okereke, 2009) opined that the financial sector in Nigeria has witnessed a host of changes as a result of financial innovation, such as increasing competition, rapid pace of technological 
innovation, legal and regulatory institutional framework, among many others. The increasing development has allowed many people to have access to financial services, especially those without prior access to these services. Supporting this view, (Shen and Lee, 2012) noted that for financial development to have a desired impact there has to be a clear channel of linkages to innovation

Financial innovation has the potential to revolutionize the financial industry to a great extent more than what happened in the past. Today, banks and non-banking financial institutions operate in a very different way than they did 20 or 30 years ago. An increasing number of clients do not need to physically visit a bank office (or the office of another type of financial institution) to deposit money, receive a loan, make a payment or transfer, or buy insurance or other financial products. The speed of transactions has also increased rapidly. Some traditional financial instruments have either disappeared or their role has decreased dramatically (Dabrowski, 2017). In Nigeria, the electronic payment platforms such as ATM, mobile banking among others, dramatically changed the financial landscape by offering customers with simple efficient, cost effective and convenient method in other to transfer money or make payments. In addition, government regulations such as the Nigerian national payment system spurred investment in technologies for instantaneous flows of finances between institutions. Specifically the introduction of e-banking system has improved the efficiency of the banking system.

\section{Empirical Review}

Darrat and Al-Sowaidi (2010) assess the role of information technology and financial deepening in Qatar, a fast growing economy. The study employs vector-errorcorrection modeling technique with its attendant short-run causal dynamics and found that real economic growth in Qatar is robustly linked over the long-run to both financial deepening and information technology and concluded that financial development, rather than IT, is more critical for enhancing economic growth over the short -run horizon.

Using the ordinary least square (OLS) method, Kenyoru (2013) empirically examined the relationship between financial innovation and financial deepening in Kenya between 2007 and 2012. financial deepening was proxies by financial inclusion(the number of depositors with commercial banks and other financial institution, while financial 
innovation was measure by mobile money innovations (number of transactions), agency banking, mobile banking (value of transactions). The study revealed that financial innovation has an insignificant positive impact on financial deepening and provides empirical evidence that mobile money innovation and mobile banking has insignificant effects on financial deepening. This simply means that the rise in mobile money transactions as well as mobile banking does not significantly influence financial deepening.

Adu, Marbuah and Mensah (2013) investigated the long run effect of financial deepening on Ghana economy, using a time series data for 14 years period 1998 - 2011. Their study used private sector credit ratio to GDP, money supply ratio to GDP, total domestic credit ratio, total bank liabilities ratio and a set of control variables such as trade openness, inflation rate and real gross government expenditure. The study, although useful in the use of more than one measure of financial deepening and the use of control variables, the number of observation of their data points is insufficient to obtain a statistically significant result for the individual variables. The researcher failed to apprehend the fact that the time span of the study draws into question the validity of the finding, as they could be spurious. Econometric theories suggest a minimum 15 years' time series data as a measure of avoiding spurious result in a study.

In the same Tee et al. (2014) assessed the role of financial development in promoting innovation-related activity in East Asian countries by Panel data analysis for the period 1998-2009. The study revealed that financial sector size and overall activity of bank and stock market exert positive influence on financial innovation. Hsu, Tian and $\mathrm{Xu}$ (2014) examined how finical market development affects technological innovation in thirty two developed and emerging countries. Their findings showed that the effect of financial development on innovation is more pronounced in emerging countries and in countries with stronger shareholder protection, weaker creditor protection.

Ndii (2016) utilized the multivariate regression analysis to establish the effects of mobile phone technology innovations on financial deepening within the banking industry in Kenya. The study found that mobile phone technology innovation explains some variance in the financial deepening of the banking industry in Kenya. Mago and Chitotwindo (2014) supported that mobile banking is filling a gap that has been 
in existence for a long time and has taken a distinct function which has traditionally, been the preserve of banks- custody of the national payment system.

Zacchaeus and Muturi (2017) examined the relationship between financial innovation and financial sector development by exploiting generalised method of moments (GMM) and time series annual data over the period of 2000 and 2015. Financial innovation was proxy by three indexes, currency money ratio, e-money and epayment, whilst financial sector development was measured by financial deepening, stock development domestic credit and foreign direct investment. The study revealed that financial innovations have significant influence on financial sector development and boosting market efficiency.

\section{Theoretical Review}

The study adopted two theories as its theoretical underpinning. This includes the supply-leading and demand-following theory and technology acceptance model.

\section{Supply-leading and Demand-following Theory}

This study is anchored on the supplyleading and demand-following hypotheses of the financial deepening-growth. The theoretical link of financial development can be traced from the seminal contribution of Schumpter (1911), supported by Gurley and Shaw (1967) through to King and King and Levine (1993) and Mckinnon (1973), among others. The hypothesis emphasizes the importance of financial service in promoting growth. The theory states that financial development occurs due to an expansion in government expenditure and in order to reach full employment, government should inject fund into the economy by increasing government expenditure. It went further to state that financial institutions and markets will advance real growth by increasing the supply of financial services.

The demand - leading hypothesis supports the idea that the creation of modern financial institutions and their financial services are in response to the demand for these services by investors and savers in the real economy (Partrick, 1966). According to this approach, the financial system adapts itself and sustains the financial needs of the real sector. An increase in economic growth will reinforce the demand of financial services leading to an expansion in the financial sector. So, the expansion of the financial system is the result of economic growth. Thus, in this view, financial markets develop and progress as a result of increased 
demand for their services from the growing real sector.

\section{Technology Acceptance Model}

The technology acceptance model was advanced by Davis (1989). This theory revolves around a person's behavior and their intention to use information communication technology (ICT). It suggest that the actual behavior of a person is determined by his/ her behavioural intention to use, which is in turn influenced by users attitude toward usefulness of the technology. Nevertheless, how users perceive technology and their attitude to be of use to them is usually determined by how easy the user can put that technology into use. Adoption of the TAM model therefore requires that the user understands the end-users requirements regarding usefulness and how user- friendly it is (Pedersen, Methlie and Thorbjornsen, 2012). Thus the value for any technology is in meeting the users' needs which again depend on their perception of how useful it is rather than an objective assessment. Those who opposed to this view disagree with its emphasis on the technical aspect of it while down playing the very important social aspects of the technology. Hence, the theory has been adopted in this study as it explains the motivation behind the various financial innovations in the commercial banks.

\section{Summary of Literature and Gap identified}

Therefore, a significant contribution of this study was the recognition that financial innovation may affect the access of financial services through multiple channels, some of which depend on the size of the financial institution, while others depend on the level of activity in financial institutions. For robust empirical investigation, the study adopts the one of the innovation since the study cannot view all the financial innovation hence, the study restrict itself to process innovation because Nigeria is a developing country. There is none in existence in Nigeria to the best of the researchers knowledge; hence this is the only study that looks at the effect of the former on the latter in Nigeria. The time frame for the study is 2011 to 2017. This period is considered because the central bank of Nigeria kicks off the business of cashless transaction in 2011, which is the latest form of financial innovations in the financial institution. Hence, this study is restricted to the period 2011 to 2017 , to examine how these innovation increases the provision of financial service to the populace. The findings of previous researchers cannot be generalize because of the peculiarity of each country, hence this study is worth 
undertaking. This study therefore intends to fill and add to these pertinent gaps in literature.

\section{RESEARCH METHODOLOGY}

The study employed a descriptive research design which expresses the situation as it is. The population of interest was commercial banks operating in Nigeria. The study covers a period 7 years between 2011 and 2017. There are currently 22 registered commercial banks on the floor of the Nigeria stock exchange. Secondary data was obtained through the $\mathrm{CBN}$ statistical bulletin, published journals and World Bank database.

\section{Model Specification}

This research work adopts the model from FSD studies on financial inclusion in Kenya and survey result from FinAccess (2009). The regression equation used is given as:

$Y=\beta_{0}+\beta_{1} X_{1}+\beta_{2} X_{2}+\beta_{3} X_{3}+\beta_{4} X_{4}+\varepsilon$

where:

$\mathrm{Y}=$ financial inclusion

$\beta_{0}=$ other factor such as government expenditure, interest rates and economic growth

$\mathrm{X}_{1=}$ Mobile Money

$\mathrm{X}_{2}=$ agency banking

$\mathrm{X}_{3}=\mathrm{M}$-banking $\varepsilon=$ probabilistic error term

In line with a detail review of previous studies, slight modification was made on the above model. This modification was made in other to achieve the stated objectives of the study. Thus, the model specification for the study is:

$\mathrm{FSD}=(\mathrm{ATM}, \mathrm{MPY}, \mathrm{NET}, \mathrm{NIB}, \mathrm{POS}, \mathrm{WET})$

The model is transformed to an econometric terms and the equation gives a multivariate relationship model below:

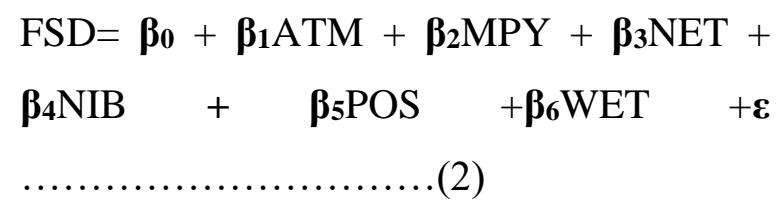

where:

$\mathrm{FSD}=$ financial sector development proxy by ratio of money supply to GDP (M2)

ATM= automated teller machine

MPY = mobile payment

$\mathrm{NET}=$ electronic fund transfer

$\mathrm{NIB}=$ Nigeria Inter Bank Settlement System

$\mathrm{POS}=$ Point of sale

$\mathrm{WET}=\mathrm{Web}$ (internet) payment.

$\beta_{0}=$ constant

$\beta_{1}-\beta_{4}=$ Coefficients,

$\boldsymbol{\varepsilon}=$ error term

According to the theoretical framework and what was found in the empirical literature the variables of interest are meticulously chosen in order to be able 
toinvestigate if there exist a relationship between financial innovation and financial sector development.

\section{RESULTS AND DISCUSSION}

This chapter presents the result of data analysis and findings.

Table 1

ADF Test Result

\begin{tabular}{lcccccc}
\hline Variable & $\begin{array}{c}\text { Adf test } \\
\text { statistics }\end{array}$ & $\begin{array}{c}\text { Test critical } \\
\text { value }\end{array}$ & $\begin{array}{c}\text { Adf test } \\
\text { statistics }\end{array}$ & $\begin{array}{c}\text { Test critical } \\
\text { value }\end{array}$ & $\begin{array}{c}\text { Stationary } \\
\text { level }\end{array}$ & Decision \\
\hline ATM & -2.926598 & -3.229230 & -7.201309 & $-4.356068^{*}$ & $\mathrm{I}(1)$ & No unit root \\
MPY & -1.614085 & -3.238054 & -4.662493 & $-4.467895^{*}$ & $\mathrm{I}(1)$ & No unit root \\
NIB & -2.091240 & -3.229230 & -5.343084 & $-4.356068^{*}$ & $\mathrm{I}(1)$ & No unit root \\
POS & -2.927132 & -3.233456 & -4.681036 & $-4.394309^{*}$ & $\mathrm{I}(1)$ & No unit root \\
WET & -5.141977 & $-4.467895^{*}$ & & & $\mathrm{I}(0)$ & No unit root \\
M2 & 0.261942 & -3.229230 & -7.382474 & $-3.653730^{* *}$ & $\mathrm{I}(1)$ & No unit root \\
NET & 1.420115 & -4.440739 & -7.011985 & $-3.653730^{* *}$ & $\mathrm{I}(1)$ & No unit root \\
\hline
\end{tabular}

\section{Source: Authors Computation 2017}

From the Augumented Dickey Fuller

Test result, all the variables were stationary at first difference form I (1) except for web/internet which is stationary at level $1(0)$.
This implies that the variables used in this study are free from the problem of spuriousness as the value of test statistic is greater than test critical value.

Table 2

ARDL Bounds Test Result

\begin{tabular}{lll}
\hline Test Statistic & Value & K \\
\hline F-statistic & 2.367719 & 6
\end{tabular}

Critical Value Bounds

\begin{tabular}{lll}
\hline Significance & I0 Bound & I1 Bound \\
\hline $10 \%$ & 2.12 & 3.23 \\
$5 \%$ & 2.45 & 3.61 \\
$2.5 \%$ & 2.75 & 3.99 \\
$1 \%$ & 3.15 & 4.43
\end{tabular}

Source: Author's Computation 2017

Table 2 presents the ARDL bounds

test procedure for the variables in order to verify if there exist long-run relationships among the variables. The test states a null hypothesis that no long-run relationships exist among the variables. The decision rule 
is to reject the null hypothesis if the F-statistic value is greater than both the I(1) bound and not to reject null hypothesis if the value is less than the $\mathrm{I}(0)$ bound. On the other hand, the test is inconclusive if the F-statistic value falls in between the bounds. The F-statistic value of the test presented above is 2.367719 . The $\mathrm{I}(0)$ and $\mathrm{I}(1)$ critical value bounds at $5 \%$ significance level are 2.45 and 3.61 respectively. This shows that the F-statistic is less than the $\mathrm{I}(0)$ bound. This indicates that the test is not significant and suggests nonrejection of null hypothesis. A conclusion can then be made that the series are not cointegrated. The leads to an estimation of first-difference ARDL model presented in Table 4.3. Since all the variables except wet are integrated of order 1 (i.e. I(1) series), they are all differenced once except wet which entered the model in its level form. 26 observations were included after adjustment for the lags and difference. Automatic model selection which follows the Akaike information criterion was used to select the optimum model and lags out of a total number of 729 models evaluated.

\section{Analysis of Results}

The result of analysis for each of the statistical tools used to provide answers to the research objectives are presented below:

\section{Result of Research Question Two and Research Hypothesis One \\ Restatement of Research Hypothesis}

$\mathrm{H}_{01}$ : There is no significant relationship between financial innovations and financial development in Nigeria.

\section{Restatement of Research Question}

Is there any relationship between financial innovations and financial sector development?

Table 3

Relationship between Financial Innovation and Financial Sector Development

\begin{tabular}{lrrrrrrr}
\hline Variable & LM2 & LATM & LMPY & LNET & LNIB & LPOS & LWET \\
\hline LM2 & 1.000000 & 0.209521 & 0.310832 & 0.133837 & 0.273204 & 0.341097 & 0.194908 \\
LATM & 0.209521 & 1.000000 & 0.436714 & 0.392872 & 0.276345 & 0.140909 & 0.312590 \\
LMPY & 0.310832 & 0.436714 & 1.000000 & 0.541017 & 0.452823 & 0.267587 & 0.383562 \\
LNET & 0.133837 & 0.392872 & 0.541017 & 1.000000 & 0.659392 & 0.557560 & 0.685039 \\
LNIB & 0.273204 & 0.276345 & 0.452823 & 0.659392 & 1.000000 & 0.281436 & 0.532034 \\
LPOS & 0.341097 & 0.140909 & 0.267587 & 0.557560 & 0.281436 & 1.000000 & 0.598862 \\
LWET & 0.194908 & 0.312590 & 0.383562 & 0.685039 & 0.532034 & 0.598862 & 1.000000
\end{tabular}

Source: Author's Computation 2017 
The correlation matrix seeks to establish and understand the degree of inter relationships that exist among variables used in the research. This was necessary to avoid the multicollinearity problem in the previous studies (Agu and M.A., 2008; Nzotta and Okereke, 2009; Nkoro and Uko, 2013). According to Tabachnick and Fidell (1996) cited in Pallant (2005) a correlation between 0 and 0.39 is a weak positive correlation, 0.40 to 0.50 is positive and moderately correlated, from 0.50 to 0.90 is positive and strongly correlated and 0.90 to 1.0 is perfectly correlated. A negative sign in a correlation matrix shows the variables are negatively correlated. However, Gujarati, Porte and Gunasekar (2012) state that if the correlation coefficient between variables in excess of

0.8 , there is multicollinearity problem. Thus, this study found no evidence of high or exact multicollinearity as all correlation coefficients are less than 0.8 bench mark. Put differently, the result above indicates absence of multicollinearity.

\section{Result of Research Question Three and Research Hypothesis Two \\ Restatement of Research Hypothesis}

$\mathrm{H}_{02}$ : Indicators of financial innovation does not have any significant effect on financial development.

\section{Restatement of Research Question}

What is the effect of each indicators of financial innovation on financial development in Nigeria?

Table 4

Effect of indicators of Financial Innovation on Financial Sector Development using first difference ARDL Model

\begin{tabular}{lllll}
\hline \multicolumn{1}{c}{ Variable } & \multicolumn{1}{c}{ Coefficient } & \multicolumn{1}{c}{ Std. Error } & t-Statistic & \multicolumn{1}{c}{ Prob.* } \\
\hline $\mathrm{D}(\mathrm{M} 2(-1))$ & 0.231332 & 0.179877 & 1.286053 & 0.2167 \\
$\mathrm{D}(\mathrm{MPY})$ & 0.017830 & 0.007341 & 2.449666 & 0.0129 \\
$\mathrm{D}(\mathrm{MPY})(-1))$ & 0.051389 & 0.021264 & 2.416713 & 0.0280 \\
$\mathrm{D}(\mathrm{NET})$ & 0.031770 & 0.064830 & 0.490055 & 0.6307 \\
$\mathrm{D}(\mathrm{NIB})$ & 0.050458 & 0.083764 & 0.602377 & 0.5554 \\
$\mathrm{D}(\mathrm{POS})$ & -0.008635 & 0.046264 & -0.186642 & 0.8543 \\
$\mathrm{D}(\mathrm{POS}(-1))$ & 0.071827 & 0.036682 & 1.958083 & 0.0679 \\
(WET) & 0.089300 & 0.040426 & 2.208974 & 0.0518 \\
$\mathrm{D}(\mathrm{ATM})$ & 0.036675 & 0.014691 & 2.496426 & 0.0239 \\
$\mathrm{C}$ & 5.743979 & 2.022184 & 2.840483 & 0.0118 \\
R-squared & 0.785680 & Mean dependent var & 9.765470 \\
Adjusted R-squared & 0.777625 & S.D. dependent var & 0.210073 \\
S.E. of regression & 0.031423 & Akaike info criterion & -3.798811 \\
Sum squared resid & 0.015799 & Schwarz criterion & -3.314928 \\
Log likelihood & 59.38455 & Hannan-Quinn criter. & -3.659470 \\
F-statistic & 122.3689 & Durbin-Watson stat & 1.843430 \\
Prob(F-statistic) & 0.000000 & \multicolumn{2}{l}{}
\end{tabular}

\section{Source: Author's Computation 2017}


The result of the model shows that the optimum model is $(1,1,0,0,1,0,0)$ which indicates that the optimum lag is M2: 1; MPY: 1; NET: 0; NIB: 0; POS: 1; WET: 0; and ATM: 0. The reported R-squared and Adjusted R-squared indicate that about 78 percent of variations in financial development is explained by the model, hence, the model is well fitted. F-statistic also shows that the overall model is statistically significant, indicated by its highly significant value of 122.3689 and p-value of 0.0000 . Durbin-Watson statistic stood at 1.84, thus, close to 2 , indicating the absence of serial correlation in the model.

The results of the coefficients of the model indicates that only the effects of MPY and its lag, lag of POS, WET and ATM are statistically significant and positive. Both contemporaneous and lag of MPY and ATM are significant at 5\% level of significance (indicated by each of their $\mathrm{p}$-value being less than 0.05) while lag of POS and contemporaneous value of WET are significant at $10 \%$ level of significance (indicated by each of their p-value being less than 0.1). Effects of other variables are not statistically significant, evident from each of their p-value being greater than 0.1. The significant effect of MPY both in its contemporaneous and lag form indicates that its effect on M2 lasts up to a period after. An increase in MPY will lead to about 0.018 and 0.051 percent points increase in ratio of M2 to GDP in the current and following periods respectively, and vice versa. The significant effect of lag of POS indicates that its effect is not felt until in the next period, and this indicates that an increase in POS will lead to about 0.072 percent points increase in ratio of M2 to GDP the next period, and vice versa. The significant effect of WET indicates that an increase in WET will lead to about 0.089 percent points increase in ratio of M2 to GDP in the current period, and vice versa. The significant effect of ATM indicates that an increase in ATM will lead to about 0.037 percent points increase in ratio of M2 to GDP in the current period, and vice versa.

From the result of the regression above $\beta_{1}>0, \beta_{2}>0, \beta_{3}>0, \beta_{4}>0, \beta_{5}>0$ and $\beta_{6}>0$ conformed to our a priori expectation, that is Automated Teller Machine(ATM), mobile payment (MPY), Nigeria electronic fund transfer(NET), Nigeria interbank (NIB), point of terminal sale(POS) and internet transaction(WET) conformed to the study expectation. Hence, this indicates that mobile money transfer, point of sale, internet payment, and automated teller machine are all financial innovations that influence the level of financial development in Nigeria. 


\section{Discussion of Findings}

The findings above suggest a significant upward increase in the growth of process innovation measured by ATM, MPY, NET, NIB, POS and WET. This clearly shows the acceptance of users of innovation. Furthermore financial innovation has a significant relationship with financial sector development following the supply leading theory. This finding agree with assertions that even though there have been key financial innovation that would change the landscape in the financial service more work still needs to be done to take advantage of the new channels to provide services that will facilitate further deepening of financial services as currently their exists some relationship between the two variables. The implication of this finding is that for process innovation to grow in Nigeria, attention must be given to the level of development of the financial system as it may continue to boost the capital accumulation efficiency and increase the level of saving.

Following a detailed ARDL analysis, the finding revealed a plausible result on financial innovation in Nigeria. The findings above suggest that financial innovation indicators have a positive and significant effect on financial sector development. A review of existing literature had suggested that financial innovation will be necessary to generate a level of access and transaction costs that makes service especially savings appropriate and affordable for all. These findings corroborate with the study of Cracknell (2012) who notes that use of various electronic platform increase the formally banked customers by increasing its customer numbers. However he provides condition for the success of these innovations which have not been tested by this model. Hence the finding rejects the null hypothesis and hence the alternative hypothesis is accepted.

\section{CONCLUSION AND RECOMMENDATIONS}

The study examined the effect of financial innovation on financial sector development in Nigeria from 2011 to 2017 using the auto regressive distributed lag (ARDL). The specific objectives were to examine the trend of financial innovation and the relationship between financial innovation and financial development in Nigeria. In the process of doing this, the hypotheses that financial innovation promotes financial sector development in Nigeria were validated. The study revealed that an upward trend of process innovation significantly influence the in depth of finance. In line with the theoretical literature, the study exhibited 
a positive relationship between financial innovations and financial sector development in Nigeria. Lastly, coefficients of the model indicates that only the effects of MPY and its lag, lag of POS, WET and ATM are statistically significant and positive. Both contemporaneous and lag of MPY and ATM are significant at 5\% level of significance (indicated by each of their p-value being less than 0.05) while lag of POS and contemporaneous value of WET are significant at $10 \%$ level of significance. Hence the study exerts a positive effect of financial innovation on financial sector development in Nigeria. The study recommends that banks and other financial institutions should make the technology more available as it will lead to the adoption of the technology by non-adopters and policy makers should design policies which will promote and enhance the relationship between financial innovation and financial development in other to increase the supply and provision of financial service

\section{REFERENCES}

Adu, J. S., Marbuah, M. O. and Mensah, M. M. (2013) 'Financial development and economic growth in Ghana: Does the measure of financial development matter?', The Journal of Development Finance, 3(12), pp. 192-203.

Agu, M. and M.A., C. (2008) 'Casual relationships between financial development, foreign direct investment and economic growth: The case of Nigeria', International Journal of Business Administration, 10(2), pp. 93-102.

Batiz-Lazo, B. and Woldesenbet, K. (2006) 'The dynamics of product and process innovation in UK banking, International Journal of Financial Services Management, 1(4), pp. 400-421.

Cracknell, D. (2012) 'Policy innovation to improve access to financial services in developing countries', Journal of Management Studies, 49(4), pp. 662-683.

Dabrowski, M. (2017) 'Potential impact of financial innovation on financial services and monetary policy', Center for Social and Economic Research, 488(2017), pp. 1-26.

Darrat, A. F. and Al-Sowaidi, S. S. (2010) 'Information technology, financial deepening and economic growth: Some evidence from a fast growing emerging economy', Journal of Economics and International Finance, 2(2), pp. 28-35.

Davis, F. D. (1989) 'Perceived usefulness, perceived ease of use, and user acceptance in information technology', Journal MIS Quarterly, 13(3), pp. 319-340.

Gennaioli, N., Shleifer, A. and Vishny, R. (2012) 'Neglected Risks, Financial Innovation and Financial Fragility', Journal of Financial Economics, 104(12), pp. 452-468.

Gujarati, N., Porte, C. and Gunasekar, S. (2012) Basic Econometrics. 5th edn. New York: Tata McGraw-Hill.

Gurley, J. and Shaw, E. (1967) 'Financial structure and economic development', Economic development cultural change, 15(1967), pp. 333-346. 
Ho, N. H. (2006) Financial innovation and its impact on Central-Bank policies.

Hsu, P., Tian, X. and Xu, Y. (2014) 'Financial development and innovation: Cross-country evidence', Journal of Financial Economics, 112(2014), pp. 116135.

Jegede, C. A. (2014) 'Effect of automated teller machine on the performance of Nigerian banks', American Journal of Applied Mathematics and Statistics, 2(1), pp. 40-46.

Kenyoru, J. (2013) Effect of financial innovation on financial development in Kenya. University of Nairobi, Kenya.

King, R. G. and Levine, K. (1993) 'Finance, entrepreneurship and growth', Journal of Monetary Economics, 33(2), pp. 513-542.

Mago, S. and Chitotwindo, S. (2014) 'The impact of mobile banking on financial inclusion in Zimbabwe: A Case for Masvingo province Mediterranean', Journal of Social Science, 5(9), pp. 1-10.

Mckinnon, R. (1973) Money and capital economic development. Washington D.C: The Brooking Institution.

Ndii M.M (2016) The effect of mobile phone technology innovations on financial deepening within the banking industry in Kenya. University of Nairobi, Kenya.

Nkoro, E. and Uko, A. . (2013) 'Financial sector development-economic growth nexus: Empirical Evidence from Nigeria', American International Journal of Contemporary Research, 10(3), pp. 87-94.

Nzotta, M. S. and Okereke, J. E. (2009)
'Financial deepening and economic development of Nigeria: An empiricalinvestigation', African Journal of Accounting, Economic, Finance and Banking, 5(5), pp. 5266.

Partrick, H. T. (1966) 'Financial development and economic growth in underdeveloped countries', Economic Development Cultural Change, 14(2), pp. 174-238.

Pedersen, P. E., Methlie, L. B. and Thorbjornsen, H. (2012) 'Understanding mobile commerce end-user adoption', Journal of Business and Economics, 13(8), pp. 53-62.

Schumpter, J. A. (1911) The Theory of Economics Development. Cambridge, US: Harvard University Press.

Shen, C. and Lee, C. (2012) 'Same financial development yet different economic growth-why?', Journal of Money, Credit and Banking, 38(7), pp. 1907-1944.

Tabachnick, B. C. and Fidell, L. S. (1996) Using multivariate statistics. 3rd edn. New York: Harper Collins.

Tee, L. T. et al. (2014) 'Financial development and innovation activity: Evidence from selected East Asian Countries', Prague Economic Journal, 2(9), pp. 162180.

Zacchaeus, N. V. and Muturi, W. M. (2017) 'The impact of financial innovation on financial sector development in Kenya', in 11th JKUAT scientific, Technological and industrialization Conference. Jomo Kenyetta. 